\title{
Marcin Pańków
}

\section{Kant i Rousseau. \\ Logika prawa a logika uczestnictwa, czyli dwie konieczności}

Tradycja uciskanych poucza nas o tym, że „stan wyjatkowy”, w którym żyjemy, nie jest wyjatkiem, ale reguła. Musimy dorobić się takiego pojęcia historii,

które temu odpowiada.

Walter Benjamin

Immanuel Kant i Jean-Jacques Rousseau chyba najbardziej spośród wszystkich nowożytnych myślicieli przyczynili się do przekładu klasycznej filozofii społecznej na współczesny język prawa i polityki. Kant nadał nowy normatywny sens pojęciu prawa i dostarczył podstaw doktrynie Rechtsstaat $^{1}$. Rousseau dał intelektualny impuls długofalowej rewolucji

Marcin Pańków (ORCID: 0000-0001-8538-9251) - doktor nauk humanistycznych, filozof i tłumacz. Adiunkt w Instytucie Filozofii Uniwersytetu w Białymstoku Zajmuje się niemieckim idealizmem, marksizmem, klasyczną filozofią społeczną i współczesną myślą krytyczną. Autor monografii Hegel i pozór (2014) oraz przedmowy do drugiego polskiego wydania Nauki logiki Hegla (2011). Kontakt: mpankow@interia.pl

1 Kant oddziałał na tym polu również za pośrednictwem Jürgena Habermasa. Por. R. Wonicki, Spór o demokratyczne państwo prawa, Wydawnictwa Akademickie i Profesjonalne, Warszawa 2007, s. 23; J. Habermas, Przedpolityczne podstawy demokratycznego państwa praworzadnego?, w: idem, Między naturalizmem a religia, przeł. M. Pańków, Wydawnictwo Naukowe PWN, Warszawa 2012, s. 91-101. Należy także wspomnieć o neokantyzmie na gruncie samej filozofii prawa, reprezentowanym zwłaszcza przez Gustava Radbrucha. Zob. G. Radbruch, Filozofia prawa, przeł. E. Nowak, Wydawnictwo Naukowe PWN, Warszawa 2009, s. 23. 
w pojmowaniu politycznego uczestnictwa i dobra wspólnego. Powołali do życia dwa klasyczne modele rozumienia idei republikańskiej i podmiotowości politycznej oraz ufundowali je w trudnych stosunkach kultury z naturą. Przedstawili dwie wykładnie granic tego, co człowiek może sztucznie skonstruować w sferze społecznej oraz politycznej jako istota uwikłana w swój przyrodzony i historyczny los. Czasem mówi się o ich pokrewieństwie, mimo różnic wynikłych z faktu, że Kantowi bliżej było do klasycznej tradycji liberalnej. Portret Rousseau wiszący w jego gabinecie miałby jednak symbolicznie dowodzić, że był on przede wszystkim myślicielem republikańskim².

W tekście tym chciałbym jednak przyjrzeć się przede wszystkim różnicy między dwoma filozofami, względnie niezależnej od etykiet politycznych. Nie zamierzam jednak w tym celu zgłębiać trudnej tożsamości politycznej Kanta i wykazywać, że bliżej było mu do liberalizmu niż do Rousseau. Będzie raczej chodzić o różnicę między dwiema logikami - lub modelami myślenia - o możliwym stosunku społecznym w kategoriach umowy. W przypadku Kanta byłby to model myślenia w kategoriach umowy jako normatywnie pojmowanej zapośredniczającej regulacji roszczeń. U Rousseau będzie to logika umowy jako formy ustanawiania wspólnego interesu i podmiotowości. Mimo podobieństw każda z tych logik odmiennie definiuje stosunki między wolnością a naturą i kulturą, między przemocą a prawem. Inaczej reguluje relację między jednostką jako bytem społecznym i jako częścią politycznego zrzeszenia. Każda odzwierciedla odmienne zalety i wady nowożytnych koncepcji umowy społecznej.

\section{1}

Model Kanta można określić mianem „logiki prawa”, ponieważ moment zaistnienia prawomocnego prawa postrzega on przede wszystkim jako ustanowienie zapośredniczającej regulacji, tak jak czynili to przed nim

2 Por. zwłaszcza M.J. Siemek, Filozofia wobec wyzwań społecznej modernizacji, w: idem, Hegel i filozofia, Oficyna Naukowa, Warszawa 1998, s. 166; J. Kloc-Konkołowicz, Portret Rousseau. Próba porównania koncepcji „woli powszechnej” z filozofią moralna i historiozofia Kanta, „Przegląd Filozoficzny" 2000, nr 1 (33), s. 39-55. 
klasyczni teoretycy umowy społecznej ${ }^{3}$. Warunki umowy społecznej określa bowiem potrzeba podporządkowania wspólnemu prawu konkurujących ze sobą jednostek, ze względu na „powszechny antagonizm”, jak czytamy w Pomystach na ujęcie historii powszechnej w aspekcie światowym. Formułując program swej filozofii historii, Kant próbuje oddać subtelną logikę uspołecznienia, dokonując śmiałej syntezy intuicji republikańskich z myślą brytyjską. Ogólną „wojnę” rodem z Lewiatana Hobbesa należy bowiem, jego zdaniem, postrzegać inaczej. Konflikt egoizmów nie stanowi przeszkody na drodze do uspołecznienia, lecz - paradoksalnie - jest kluczem do jego wyjaśnienia, ponieważ wynika z pewnej trudno uchwytnej cechy natury ludzkiej. Jest to cecha ambiwalentna: „aspołeczna towarzyskość ludzi (ungesellige Geselligkeit der Menschen)”, „aspołeczna chęć urządzenia wszystkiego wedle własnego upodobania". Jak wyjaśnia Kant:

[...] ten to właśnie opór mobilizuje wszystkie siły człowieka, sprawia, że przezwycięża on swoją skłonność do lenistwa i gnany ambicją, żądzą władzy lub bogactwa, dąży do zdobycia sobie pozycji wśród bliźnich, których nie może znieść, ale i nie może się bez nich obyć. Dopiero wtedy zostaje dokonany pierwszy prawdziwy krok od barbarzyństwa do cywilizacji, która w istocie polega na społecznej wartości człowieka. Wtedy też zaczynają się stopniowo rozwijać wszelkie talenty, wykształca się smak, a dzięki postępującemu oświeceniu zostają położone podwaliny pod taki sposób myślenia, przy którym prymitywne zadatki przyrodzone rozeznania moralnego będą się mogły z czasem przeobrażać w określone zasady praktyczne, dzięki czemu [...] wymuszona zgoda na życie w społeczeństwie będzie się mogła wreszcie przekształcić w związek moralny ${ }^{4}$.

Rozpoznanie Kanta jest dialektyczne. Aspołeczna towarzyskość wyjaśnia, w jaki sposób konflikt egoizmów przeradza się immanentnie w swoje

3 We wprowadzeniu do swej teorii prawa zewnętrznego, pod najbardziej ogólnym hasłem „Czym jest prawo?”, Kant podaje takie oto wyjaśnienie: „Istota tego stosunku polega bowiem na tym właśnie, że wola arbitralna jednej osoby odniesiona jest do woli arbitralnej (lub samowoli) drugiej osoby. [...] Pytamy tu wyłącznie o formę wzajemnego stosunku [Form im Varhältnis], w który obie te wole wstąpiły, w takim wymiarze, w jakim można je uznać za wolne [frei], a ponadto - czy możliwe jest uzgodnienie na mocy prawa powszechnego wolności jednej woli podejmującej określone działanie z wolnością innej woli". I. Kant, Metafizyka moralności, przeł. E. Nowak, Wydawnictwo Naukowe PWN, Warszawa 2005, s. 40-41.

4 I. Kant, Pomysty do ujęcia historii powszechnej w aspekcie światowym, w: idem, Przypuszczalny początek ludzkiej historii, przeł. M. Żelazny, Comer, Toruń 1995, s. 39. Wszystkie wyróżnienia w cytatach, zaznaczone kursywą, pochodzą od autora. 
przeciwieństwo, w nowego typu wspólnotę, w „związek moralny”. Proces wyłaniania się społecznych dystynkcji w warunkach zaawansowanego podziału pracy dopiero stwarza "społeczną wartość” poszczególnego człowieka. Co więcej, wytwarza w ogóle wartości jako takie, kształtuje coś wspólnego. Przyrodniczy przymus uspołecznienia w stanie natury wymusza na nieufnych jednostkach chęć współpracy, samodoskonalenia i koordynacji pierwotnie egoistycznych działań. Zadaniem oświeconych rządzących i opinii publicznej jest zatem świadome uznanie tej pozytywnej tendencji i poparcie jej. Proces przechodzenia od barbarzyństwa do cywilizacji trzeba usankcjonować $\mathrm{w}$ wymiarze powszechnym poprzez wprowadzenie formalnego systemu regulacji - racjonalnego prawodawstwa:

Przeto najwyższym zadaniem, jakie przyroda postawiła przed rodem ludzkim, musi być społeczeństwo, w którym wolność przy poszanowaniu praw zewnętrznych łączy się w stopniu możliwie najwyższym z nieodpartym przymusem, tzn. doskonale sprawiedliwy ustrój obywatelski ${ }^{5}$.

Istota wolności obywatelskiej polega na równowadze między uprawnieniami podmiotu a bezwzględnym poszanowaniem granic tych uprawnień. Przypomnijmy, że kreśląc taką perspektywę „ustroju obywatelskiego”, Kant powołuje w tym samym czasie - performatywnie - do istnienia nowoczesną opinię publiczną na łamach „Berlinische Monatschrift”. Umiarkowany wydźwięk słynnego eseju zatytułowanego Co to jest oświecenie? ${ }^{6}$ - „myślcie, ale bądźcie posłuszni!” - wynikał zapewne z tego samego przeświadczenia: sprawiedliwy ustrój polityczny nie powstaje w wyniku zerwania z nieznośnym stanem natury - jak u Hobbesa lub Rousseau. Wbrew temu ostatniemu nie polega na przywróceniu jednostce utraconej integralności moralnej, jej „drugiej natury”. Stan prawny Kant postrzega jako legitymizację spontanicznych procesów uspołecznienia i prymitywnej racjonalności ekonomicznej, jako kontynuację kulturotwórczego procesu innymi środkami. Państwo praworządne, które hołduje zasadzie wolności słowa, jest tylko przedłużeniem i udoskonaleniem natury ${ }^{7}$.

5 Ibidem, s. 41.

6 I. Kant, Co to jest oświecenie?, w: idem, Przypuszczalny poczatek..., s. 52-60.

7 W rozprawie $O$ wiecznym pokoju, w której mowa jest o „państwie diabłów”, problem zostaje ujęty w sposób mniej obrazowy, ale w gruncie rzeczy chodzi o to samo: „Problem taki jak ten 
Wydawałoby się zatem, że Kant podąża tropem brytyjskich myślicieli Oświecenia. Jednak już u Locke’a porządek polityczny miał na celu tylko zabezpieczenie istniejących wcześniej praw naturalnych. Tymczasem królewiecki myśliciel częściowo skłania się ku tezie Hobbesa, iż „gdzie nie ma państwa, nic nie jest niesprawiedliwe". Dopiero ustanowienie publicznej władzy uprawomocnia, zdaniem Kanta, prawo własności oraz podstawowe prawa każdego człowieka. Rozpatrywane w horyzoncie publicznej sprawiedliwości tracą one status czegoś li tylko „prowizorycznego”. Przede wszystkim jednak Kant posuwa się przy tym do charakterystycznej interpretacji samej sprawiedliwości: ustrój sprawiedliwy sprowadza się do ochrony obywateli i ich „praw zewnętrznych” popartej „nieodpartym przymusem” („Freiheit unter äusseren Gesetzen [...] mit unwiderstehlichen

musi być rozwiązywalny, bo nie chodzi tu o moralne ulepszanie człowieka, lecz o mechanizm natury, co do którego trzeba wiedzieć, w jaki sposób dałby się zastosować do ludzi, ażeby sprzeczność ich nieprzyjaznych skłonności w obrębie narodu tak skorygować, by sami oni zniewalali się nawzajem do podporządkowania się pod zniewalające prawa i w ten sposób urzeczywistniali stan pokoju, w którym prawa mają moc". I. Kant, Do wiecznego pokoju. Projekt filozoficzny, przeł. M. Żelazny, Comer, Toruń 1995, s. 74.

8 T. Hobbes, Lewiatan czyli Materia, forma i władza państwa kościelnego i świeckiego, przeł. Cz. Znamierowski, Państwowe Wydawnictwo Naukowe, Warszawa 1954, s. 127.

9 „Pierwsze potrzeby życiowe, których spełnienia wymagał zróżnicowany tryb życia, mogły być teraz zaspokajane na drodze wymiany. Tu rozpoczyna się kultura, jak również sztuka, i to zarówno czasu wolnego, jak i wykonywana w celach pracy. Co jednak najistotniejsze, powstaje również swego rodzaju zalążek przyszłego społeczeństwa obywatelskiego i sprawiedliwości, początkowo naturalnie odnoszącej się tylko do największych gwałtów, za które pomsty nie domagała się już jednostka, ale prawodawcza moc spajająca całość, a zatem coś w rodzaju rządu, niezależnie od którego nie mogło mieć miejsca żadne sprawowanie władzy. Z tej pierwszej i surowej jeszcze predyspozycji mogły się stopniowo rozwinąć wszelkie ludzkie sztuki, wśród których najbardziej dobroczynna jest sztuka życia towarzyskiego i obywatelskiego bezpieczeństwa. Rodzaj ludzki mógł się rozmnażać i podobnie jak ul pszczeli rozprzestrzeniać, startując z centralnego punktu i rozsyłając wszędzie wykształconych już kolonistów. Wraz $\mathrm{z}$ epoką tą powstaje też i zaczyna się potęgować nierówność pomiędzy ludźmi, owo bogate źródło tak wielorakiego zła, a równocześnie wszelkiego dobra”. (I. Kant, Co to jest oświecenie..., s. 29. „Stan naturalny jest siedliskiem niesprawiedliwości (iniustus) nie z tej przyczyny, że stosunku między ludźmi oparte tam były na gwałcie i przemocy; był to przecież stan bezprawia (status iustitia vacuus), w którym skoro tylko jakieś prawo stało się źródłem sporu (ius controversum) - nidzie nie można było znaleźć sędziego zdolnego wydać kompetentny wyrok [...] bo chociaż według wszelkich danych prawo dopuszczało tam nabywanie przedmiotów zewnętrznych w drodze zajęcia bądź umowy, wszystko to miało charakter prowizoryczny" (I. Kant, Metafizyka..., s. 153-154). 
Gewalt") ${ }^{10}$. Tym samym sam narzuca polityczną interpretację swej koncepcji. Ustrój wolności to, paradoksalnie, porządek konieczności - porządek niezbędnej formalizacji stosunku społecznego. Porządek taki wprawdzie wyłania się z natury, ale ukoronowaniem tego procesu jest sztuczna władza prawnego przymusu. Płynna i nieokreślona przestrzeń „naturalnych" relacji między grupami i jednostkami w ich konfliktach i aliansach, której współrzędne dotąd wyznaczały „prymitywne zadatki rozeznania moralnego", sama z siebie domaga się prawomocnej formalizacji. Reguły społecznego działania muszą zostać usankcjonowane przez władzę państwa praworządnego.

Koncepcja Kanta charakteryzuje się zatem ścisłym powiązaniem dwóch elementów: legalizmu oraz legalistycznej wykładni wolności i sprawiedliwości à la Hobbes, a także języka moralnej i cywilizacyjnej powinności. Dla autora Krytyki praktycznego rozumu prawo pozytywne czerpie bowiem swój majestat i moc wciąż tylko z uniwersalnego prawodawstwa tegoż. Towarzyszy temu bardziej pokojowa wizja stanu natury, bliższa oświeceniowym koncepcjom homo oeconomicus w wydaniu Locke'a, Smitha i Hume'a niż „wojnie wszystkich przeciwko wszystkim”. Ogólny obraz sytuacji przywodzi więc także na myśl teorię sformułowaną dwieście lat później przez Jürgena Habermasa: przedpolityczne „światy życia”, w myśl weberowskiej zasady racjonalizacji, muszą być kolonizowane przez nowoczesne systemy władzy. Kantowska powinność czynienia „publicznego użytku z rozumu” przez intelektualistów wolnych od „obcego kierownictwa" (wolność słowa) to krytyczna opinia publiczna jako zinstytucjonalizowana forma wspólnego działania komunikacyjnego. Na tle republikańskiej z ducha teorii demokracji Habermasa tym bardziej rzuca się w oczy kontrast między hobbesowską wizją sprawiedliwości jako zewnętrznego przymusu i gwarancji umów a nową ideą prawa moralnego ufundowanego w uniwersalizmie rozumu. Jak interpretować ów dualizm i czy rzeczywiście jest to dualizm? Zapewne hobbesizm Kanta nie jest tylko oznaką politycznego konserwatyzmu pruskiego filozofa i jego motywacji trzeba też szukać w potrzebach epoki. Przyjrzyjmy się jeszcze uzasadnieniu szóstej tezy z Pomysłów do ujęcia historii powszechnej w aspekcie światowym. 
Ustrój obywatelski rozumiany jako ścisła regulacja praw zewnętrznych zostaje w myśl szóstej tezy uznany za „zadanie najtrudniejsze”, które zostanie też „najpóźniej wypełnione przez rodzaj ludzki”. Trudność ta ma wynikać z faktu, że człowiekowi właściwy jest „egoistyczny popęd zwierzęcy”. Popęd ten będzie sprawiał, że człowiek „nadużyje wolności w stosunku do istot sobie podobnych", zawsze koniec końców czyniąc dla siebie wyjątek spod prawa. Tymczasem z przyczyn racjonalnych winien postępować $\mathrm{w}$ taki sposób, aby jego wolność mogła współistnieć z wolnością cudzą i poddać się „woli powszechnie obowiązującej”"1. Również w Metafizyce prawa Kant podkreśla, że samoograniczenie wolności nie polega na tym, że ja sam sobie je narzucam, lecz że odnajduję swą wolność już z góry w taki sposób ograniczoną ${ }^{12}$. Tutaj właśnie wychodzi na jaw związek koncepcji prawa zewnętrznego $\mathrm{z}$ formułą imperatywu kategorycznego - logiki „państwa diabłów” z logiką „państwa celów”"13. Stając się podmiotami, musimy zrozumieć, że naszym wspólnym losem jest wolność, ale taka, która z istoty „podlega ograniczeniu w aspekcie idealnym i może być też czynnie ograniczana przez innych"14. Ponieważ jednak nie zawsze jesteśmy do niego zdolni, to - zauważa Kant - „potrzebujemy pana”, by ten „złamał w nas wolę własną i zmusił do posłuszeństwa woli powszechnie obowiązującej"15. Jest to niemal jawne nawiązanie do woli powszechnej

11 I. Kant, Pomysty..., s. 41.

12 I. Kant, Metafizyka..., s. 42.

13 „Problem zorganizowania państwa jest rozwiazywalny, mówiąc bez ogródek, nawet dla narodu diabłów", czyli dla zrzeszenia istot, z których każda skłonna jest w tajemnicy uchylać się od przestrzegania prawa (I. Kant, Do wiecznego..., s. 74). Inaczej w moralnym „państwie celów”, w którym każda istota rozumna jest „zwierzchnikiem, czyli prawodawcą, ale miejsce zwierzchnika może jednak zająć nie przez samą maksymę swej woli, lecz dopiero wtedy, gdy jest istotą zupełnie niezależną, bez potrzeb”. Dlatego „państwo celów” z zasady pozostaje tylko nierzeczywistym ideałem.

14 Por. I. Kant, Metafizyka..., s. 42: „Wobec takiego stanu rzeczy powszechna zasada prawa, która głosi: postępuj na zewnątrz w taki sposób, ażeby wolny użytek, jaki czynisz ze swojej woli, mógł współistnieć z wolnością każdego zgodnie z prawem powszechnym, nakłada na nas pewne zobowiązanie. Jednakże nie oczekuje ona, ani tym bardziej nie żąda ode mnie, abym to ja sam dokonał ograniczenia mojej wolności, gwoli dopełnienia swojego zobowiązania. Rozum orzeka tutaj jedynie tyle, że moja wolność podlega ograniczeniu w aspekcie idealnym i może być też czynnie ograniczana przez innych. Rozum wyraża to ostatnie w formie postulatu, który nie wymaga już żadnych dodatkowych dowodów". 
Rousseau, choć „popęd zwierzęcy” oraz chłodny realizm samego argumentu znów łatwo przywodzą na myśl Hobbesa. Z jednej strony prawo jest wprawdzie tylko o tyle prawem słusznym, o ile podlega warunkowi uniwersalizacji. Albo - jak powiedziałby Kant - jest sprawiedliwe, jeśli „mogłoby” zostać ustanowione wspólnie przez wszystkich jako obywateli. Sam akt zawarcia umowy społecznej postrzega on jednak jako „czystą ideę rozumu", sytuację, którą należy praktycznie założyć, aczkolwiek nie jest ona nawet możliwa jako fakt ${ }^{16}$. Z drugiej jednak strony w szerszej skali trzeba się liczyć z koniecznością „łamania woli” członków społeczeństwa, dodaje pragmatycznie w Pomystach... . Jednostka jako obywatel „państwa diabłów” jest potencjalnie niebezpieczna, mimo że jej powołaniem kulturowym jest racjonalne uznanie dla powszechnego prawa ${ }^{17}$. Zza portretu Rousseau ze ściany Kantowskiego gabinetu co chwila wyziera twarz Hobbesa. Przyjrzyjmy się teraz Umowie społecznej, która powinna rzucić nowe światło na tę dwuznaczność koncepcji Kanta.

\section{2}

Rousseau konstruuje swój model umowy społecznej w świadomym dystansie wobec klasycznego ujęcia liberalnego. Punktem wyjścia nie jest poszczególny podmiot w jego stosunku do prawa, lecz akt ustanowienia woli powszechnej (la volonté générale) w relacji sumowania się woli wszystkich oraz określenie jej stosunku do woli wszystkich (volonté de tous). Problemem do rozwiązania nie jest stan natury jako przedpolityczna kondycja człowieka, której neutralizacją lub udoskonaleniem byłby obywatelski stan prawny. Krytyczna diagnoza dotyczy relacji między naturą a kulturą. Człowiek nieuchronnie wyszedł ze stanu bezrefleksyjnej niewinności i stał się dzieckiem cywilizacji. Ta jednak w swym rozwoju zatoczyła błędne

16 I. Kant, O porzekadle, w: idem, Do wiecznego..., s. 27. „Umowa ta jest czysta ideq rozumu, posiadającą jednakże niewątpliwą (praktyczną) realność w tym mianowicie znaczeniu, że nakłada ona na każdego prawodawcę obowiązek ustanowienia swych praw tak, jak gdyby wraz z innymi mogły one wynikać ze zjednoczonej woli całego narodu i by każdego poddanego, o ile chce być on obywatelem, rozpatrywać tak, jak gdyby wraz z innymi dał on na taką wolę swoją zgodę".

17 W sprawie „państwa diabłów” zob. przypis 13. 
koło i uspołecznienie, a nawet samo oświecenie, wpędziło ludzi na powrót w hobbesowski stan natury. Kultura, zamiast wyzwolić pełen potencjał człowieczeństwa, odtworzyła w swym łonie stan natury w postaci refleksyjnej, jako społeczne $z^{\prime 10}{ }^{18}$. Jest to sytuacja skrajnej niepewności, będąca namacalnym zaprzeczeniem zarówno natury, jak i uniwersalistycznie pojmowanej idei człowieczeństwa.

Problem stanu obywatelskiego nie jest już zatem usytuowany w typowym nowożytnym kontekście kolizji uprawnień jednostkowych z wymogiem powszechnego bezpieczeństwa. Główną stawką jest już autonomia polityczna wszystkich ludzi, możliwość demokracji oraz integralność człowieka w wymiarze uniwersalnym, moje ,ja” wobec wszystkich i wszyscy wobec „ja”. Chodzi o poszukiwanie wspólnej autonomii w świecie powszechnej walki o władzę i przetrwanie - zwłaszcza o status, pieniądze i prestiż. A ponieważ temu wszystkiemu towarzyszy szkodliwa tendencja do podziału pracy w sferze polityki, to przetrwanie demokracji w świecie nowoczesnym jawi się jako mało prawdopodobne, jeśli wręcz nie niemożliwe ${ }^{19}$.

Jeżeli jednak chcielibyśmy myśleć o trudnym wyjściu z takiego cywilizacyjnego "stanu natury” budując zrzeszenie polityczne nowego typu, to tym razem umowa społeczna musiałaby być radykalnym aktem zerwania. Jak powiada Rousseau, taki akt powinien tworzyć „ciało moralne i zbiorowe [...] uzyskujące przez ten akt swoją jedność, swoje wspólne «ja», swoje życie i wolę"20. Ustanawiałby on „wolę powszechną" jako autonomiczny polityczny podmiot i tym, co należałoby odtąd określać, byłaby relacja między jednostkami i ich wolą a tą wspólną wolą polityczną. Jest to właśnie relacja uczestnictwa, ponieważ wola ta jest podmiotem jedynie $\mathrm{w}$ sensie idealnym, manifestuje się tylko $\mathrm{w}$ sformalizowanych procedurach

Por. J.J. Rousseau, Rozprawa o pochodzeniu i podstawach nierówności między ludźmi, w: idem, Trzy rozprawy z filozofii społecznej, przeł. H. Elzenberg, Państwowe Wydawnictwo Naukowe, Warszawa 1956, s. 107-278, zwłaszcza s. 224-228.

„Biorąc rzecz w znaczeniu ścisłym, prawdziwa demokracja nigdy nie istniała i nigdy istnieć nie będzie [...]. Nie można sobie wyobrazić, by lud był ustawicznie zgromadzony dla załatwiania spraw publicznych, a łatwo zrozumieć, że nie może ustanawiać w tym celu komisyj bez zmiany formy rządu”. A dalej: „Gdyby istniał lud złożony z bogów, miałby rząd demokratyczny. Tak doskonały rząd nie nadaje się dla ludzi". J.J. Rousseau, Umowa społeczna, przeł. A. Peretiakowicz, Wydawnictwo Naukowe PWN, Warszawa 2010, s. 72-73. 
działania politycznego. I jedynie za sprawą tego idealnego charakteru jej istnienie można uznać za równoznaczne z jej autonomią bądź suwerennością. Jak podkreśla Rousseau:

[...] wola powszechna jest zawsze słuszna i zmierza zawsze ku pożytkowi ogółu; nie wynika stąd jednak, że obradom ludu przysługuje zawsze w równym stopniu trafność. Każdy pragnie zawsze swego dobra, ale nie zawsze je dostrzega ${ }^{21}$.

Zgodnie z logiką stosunku części do całości poszczególne podmioty $\mathrm{w}$ ich woli są czymś nieuchronnie partykularnym. Zostają naznaczone różnicą, którą można określić mianem epistemicznej. Każdy jest sam w sobie nośnikiem woli powszechnej - jako politycznego ucieleśnienia czystego człowieczeństwa - która wiąże jego indywidualny interes z interesem ogółu. Często nie jest nim jednak „dla siebie”, ponieważ niemal nigdy nie ma w ową wolę odpowiedniego wglądu. Czynniki historyczne sprawiają, że zostaje naznaczony trwałą sprzecznością między byciem obywatelem (jako citoyen) a alienacją w ramach społecznej gry kapitałów. Gry władzy ekonomicznej, statusu, koneksji i prestiżu sprawiają, że stacza się nieuchronnie $\mathrm{w}$ hobbesowski stan natury (jako burgeois) ${ }^{22}$. Jedynym wyjściem z impasu jest radykalny akt rezygnacji z własnej samoistności oraz bezwarunkowa inwestycja we wspólną tożsamość z innymi, którzy na szczęście - znajdują się przynajmniej w podobnej sytuacji.

Każdy oddając się wszystkim nie oddaje się nikomu, a ponieważ każdy ze stowarzyszonych nabywa nad innymi te same prawa, które im względem siebie odstępuje, każdy uzyskuje ekwiwalent tego, co traci, i zdobywa więcej siły, by zachować to, co ma [...]. „Znaleźć formę stowarzyszenia, która by broniła i chroniła całą wspólną siłą osobę i dobra każdego człowieka, i dzięki której każdy, łącząc się ze wszystkimi, słuchałby jednak tylko siebie i pozostał równie wolny jak przedtem". Oto problem zasadniczy, który rozwiązuje umowa społeczna [contrat social] ${ }^{23}$.

21 Ibidem, s. 34.

22 Jak zauważa Jürgen Habermas: „Rousseau twierdzi, że ów stan, w którym rządzi polityczne zło naturalne i który zmusza do uspołecznienia, w despotycznie narzuconym stanie społecznym bynajmniej nie zostaje zniesiony, ale wraz z konkurencją prywatnych interesów trwa nadal w obrębie nie znającego spokoju i rozdartego systemu podzielonej pracy i zwielokrotnionych potrzeb". J. Habermas, Prawo naturalne a rewolucja, przeł. M. Łukasiewicz, w: idem, Teoria i praktyka, Państwowy Instytut Wydawniczy, Warszawa 1983, s. 128. 
Umowa jako inwestycja we wspólną autonomię ma charakter bezwarunkowy. Kontrahent zostaje niejako postawiony w pascalowskiej sytuacji wyboru absolutnego, w której to, co traci, okazuje się niczym wobec tego, co zyskuje. Rezultatem tego aktu nie jest jednak jakaś religijna rezygnacja z własnego „ja” i oddanie się Wspólnocie niczym wspólnemu bogu. Przeciwnie - Rousseau nie przypadkiem posługuje się terminem „ekwiwalent”. Sygnalizuje, że decyzja może tu być wręcz wynikiem kalkulacji czysto ekonomicznej. Celem umowy jest zresztą wciąż tylko odzyskanie przez jednostkę utraconej autonomii i integralności poprzez pozyskanie na użytek własny „większej siły”. Nawiązanie relacji politycznego uczestnictwa jest nadal umową, porozumieniem ustalającym wzajemne prawa i obowiązki.

Spróbujmy wstępnie porównać obie koncepcje. Ich wspólną cechą jest niewątpliwie interpretacja wolności jako koniecznego samoograniczenia ${ }^{24}$. Akt umowy w projekcie Rousseau wymaga wręcz wyzbycia się naszego "ja hobbesowskiego" z jego fałszywymi potrzebami i interesami. To wyzbycie się ma jednak być odzyskaniem siebie, ponieważ w akcie umowy człowiek miałby odnajdywać na nowo swój szczegółowy interes we wspólnym „ja”. Świadom sprzeczności między citoyen a burgeois - aktywnym politycznie obywatelem a prywatnym człowiekiem interesu - Rousseau musi uznać, że stan wolności wiąże się z tego powodu z nieusuwalnym konfliktem poznawczym i egzystencjalnym. Zupełnie inaczej jest u Kanta, dla którego bycie obywatelem jest niejako reprezentowane przez podmiot określonego interesu prywatnego w jego tożsamości (jako właściciela ziemskiego, rzemieślnika itd.). Człowiek jest nieuchronnie związany ze swoim „ja” hobbesowskim jako burgeois i dlatego „potrzebuje pana” ${ }^{25}$. Podporządkowanie się prawu w szacunku dla jego racjonalnego majestatu jest ostatecznie aktem pragmatyzmu. Wynika ze świadomości powszechnej potrzeby bezpieczeństwa w sytuacji stopniowego przechodzenia od społecznego stanu natury do doskonałego ustroju obywatelskiego. 
Różnica ta odzwierciedla się w odmiennym stosunku do reprezentacji politycznej oraz w ocenie form ustrojowych. Kant w ogóle nie uznaje demokracji bezpośredniej, równoznacznej dlań z brakiem republikańskiej formy podziału władzy: prawodawca nie może być zarazem wykonawcą swej woli. Co więcej, demokracja w ogóle jest „z konieczności despotyzmem” ogółu, gdyż o jednostce „decydują wszyscy, którzy jednak nie są wszystkimi, co stanowi sprzeczność powszechnej woli z sobą samą i z wolnością"26. Dla Rousseau natomiast władza republikańska może się przejawiać w różnych formach stosunku między ludem (jako ogólną władzą ustawodawczą) a rządem. Wybór odpowiedniej formy ustrojowej rządu zależy od wielkości państwa, ale jedna zasada pozostaje niezmieniona: „woli powszechnej się nie reprezentuje" (i dlatego Anglicy przestają być niewolnikami tylko $\mathrm{w}$ dniu wyborów ${ }^{27}$ ). Może ona tylko lepiej lub gorzej przejawiać się w obradach całego ludu jako wypadkowa równowagi sił społecznych i świadomości wspólnego interesu. Jej stopniowe urzeczywistnienie czyniłoby koniec końców zbędnym również samo państwo. W pierwszym przypadku - dla Kanta - państwo praworządne stanowi horyzont ostateczny, w drugim jego celem jest stopniowe wyzwolenie od przymusu prawnego, czyli zniesienie warunków, które stanowiły o konieczności zawarcia umowy ${ }^{28}$.

Mimo tych rozbieżności oba modele mają jedną cechę wspólną: jest nią wymóg bezwarunkowości umowy odziedziczony po Hobbesie. Obydwa pod tym względem rządzą się logiką konieczności: Kant wydaje się tu występować niejako z ramienia konieczności cywilizacyjnej, Rousseau natomiast jest rzecznikiem konieczności o charakterze przede wszystkim egzystencjalnym. Dla Kanta umowa dostarcza koniecznej sankcji możliwej wartości społecznej, dla Roussseau bez umowy wartość ta nie może już po prostu zaistnieć; obojętnie, czy nazwiemy ją wolnością, dobrem, czy podmiotowością. W tym sensie najwyższą zasadą polityki w pierwszym przypadku musi być prawo, w drugim - uczestnictwo.

I. Kant, Do wiecznego..., s. 59.

J.J. Rousseau, Umowa..., s. 98. Tezy, że woli powszechnej nie można reprezentować oraz że prawodawca nie może być zarazem wykonawcą swej woli, nie są przeciwstawne. Rousseau próbuje raczej zachować możliwość demokracji bezpośredniej w ramach republikańskiej formy podziału władz - nawet jeśli bliski jest uznaniu jej realnej niemożliwości z innych przyczyn. 
Jak z dzisiejszego punktu widzenia możemy oceniać obie koncepcje? Kant wywołuje naturalnie mniej kontrowersji niż autor Umowy społecznej. Na pierwszy rzut oka wydaje się bardziej wiarygodny, bo ze sceptycyzmem podchodzi do realizacji ideałów w świecie ziemskim oraz stawia wyraźną granicę między porządkiem moralnym a porządkiem legalnym ${ }^{29}$. Wynika to stąd, że Kant, tak jak my, też jest bardziej liberalny. Wierzymy bowiem zwykle, że nasza podmiotowość jest czymś danym przed umową. Również treść możliwego prawa stanowionego wydaje się już intuicyjnie obecna i dlatego nie może się stać przedmiotem sztucznej konstrukcji politycznej. Musimy jednak pamiętać, że właśnie lektura Umowy społecznej skłoniła Kanta do wyłamania się z tradycji prawa naturalnego, która do takich intuicji się odwoływała. To właśnie Rousseau jako „postać z portretu” zainspirował go swą koncepcją woli powszechnej, gdy konstruował logiczny schemat imperatywu kategorycznego, który z kolei służy za wzorzec dla jego wizji prawa zewnętrznego. Co więcej, Rousseau był właśnie tym myślicielem, który za pośrednictwem rewolucji francuskiej ukształtował również nasze rozumienie siebie jako autorów prawa także w wymiarze politycznym, a w centrum zainteresowania postawił nader aktualny problem alienacji klasy politycznej. Mimo to - albo właśnie dlatego - zagrożenia polityki opartej na jego teorii wychodzą na jaw stosunkowo łatwo, o czym świadczy krytyka przeprowadzona przez Hannah Arendt. Przyjrzyjmy się jej przez chwilę.

Arendt zauważa, że żaden z rządów wyłonionych w czasie rewolucji francuskiej „nie został wyłoniony z ludu ani przez lud”30, mimo że właśnie

Kant był sceptyczny w kwestii możliwości osiągnięcia przez człowieka szczęścia indywidualnego, nie mówiąc już o szczęściu powszechnym. Racjonalność praktyczna oparta na symetrii zobowiązań i oczekiwań jest raczej autorytetem, któremu człowiek musi się podporządkować jedynie po to, aby być w ogóle godnym szczęścia. Człowiekowi w jego egzystencji zawsze towarzyszy przymus, albowiem nie tylko relacje między nim a innymi, ale i jego samego przenika nieuchronny antagonizm między skłonnościami a obowiązkiem. Dlatego na gruncie teorii moralności państwo celów jako postulowanej republiki wolnych prawodawczych istot, istnieje tylko w świecie myśli i może zyskać realną podstawę co najwyżej za pośrednictwem racjonalnej wiary religijnej. Natomiast doskonale sprawiedliwy ustrój obywatelski, w którym obecny jest moment przymusu, jest możliwy w odległej przyszłości w świecie ziemskim. H. Arendt, O rewolucji, przeł. M. Godyń, Wydawnictwo X, Kraków 1991, s. 74. 
za sprawą Rousseau „lud” zyskał status uniwersalnego podmiotu pogrążonego w politycznym nieszczęściu. Atrakcyjność jego koncepcji dla jakobinów i innych antyliberalnie nastawionych radykałów polegała na tym, że pojęcie woli powszechnej było pomysłowym sposobem na zastąpienie wielości jednością. Według Arendt teza o „niepodzielności” woli powszechnej jest maską dla zwykłej jednomyślności pokrywanej frazesami o woli ludu (lub racji stanu). W dyskursie jakobinów pełni ona funkcję ideologiczną, jest fikcyjnym źródłem domniemanej wspólnej podmiotowości. Dlatego z procesu kształtowania wspólnej woli w rewolucyjnej Francji zostaje wyrugowany wymiar polityczności, inaczej niż w Ameryce, gdzie jest stale obecny pod postacią uznanych reguł i kultury gry politycznej - sztuki sporu, wymiany opinii i kompromisu jako form sublimacji konfliktu. Rousseau natomiast miał niejako zmusić jakobinów, aby zastąpili polityczność odniesieniem do „wewnętrznego wroga”:

Rousseau rozwiązał problem następująco: wróg taki żyje w piersi każdego obywatela, pod postacią jego partykularnej woli i interesów [...] wola powszechna jest artykulacją wspólnego interesu, a więc interesu ludu bądź narodu jako całości. A ponieważ ów interes (czyli wola) jest powszechny, przeto samo jego istnienie zależy od tego, czy przeciwstawimy go każdemu interesowi poszczególnemu lub każdej partykularnej woli [...]. Aby więc uczestniczyć w politycznym życiu narodu, każdy obywatel musi zbuntować się przeciwko sobie samemu i trwać w tym buncie bez ustanku $\mathrm{u}^{31}$.

Rousseau, rzecz jasna, nie był aż tak antyliberalny, jak przedstawia go Arendt, i zarazem był zbyt republikański, aby nie uświadamiać sobie możliwych konfliktów w tym kluczowym polu napięcia swej teorii. Widać to w kolejnych księgach Umowy społecznej, w których konstrukcja pojęciowa woli powszechnej podlega konkretyzacji. Wprawdzie „im większa zgoda panuje w zgromadzeniach, to znaczy im bardziej zdania zbliżają się do jednomyślności, tym bardziej przeważa wola powszechna”. Jednak na drugim biegunie - dodaje - „[... jednomyślność powraca; wtedy mianowicie, gdy obywatele popadłszy w niewolę, nie mają już ani wolności, ani woli. Wówczas obawa i pochlebstwo zamieniają głosowanie w aklamację. Już się 
nie obraduje, lecz uwielbia lub złorzeczy"32. Rousseau przeprowadza też interesującą specyfikację możliwych form stosunku między „zwierzchnikiem”, czyli ludem, a „rządem” (lub „księciem”) jako władzą wykonawczą. Zwraca tu uwagę na dwie skrajne możliwości:

Jeżeli cały rząd znajduje się w rękach jednego człowieka, wola partykularna i wola ciała rządzącego są zupełnie zjednoczone i ta ostatnia ma wobec tego najwyższy możliwy stopień nasilenia. Ponieważ zaś od stopnia woli zależy użycie siły, a siła absolutna rządu się nie zmienia, przeto najaktywniejszym rządem jest rząd jednoosobowy.

Jeżeli, przeciwnie, połączymy rząd z władzą ustawodawczą, zrobimy zwierzchnika księciem, a wszystkich obywateli urzędnikami, wówczas wola ciała, złączona z wolą powszechną, nie będzie bardziej od niej czynna i pozostawi wolę partykularną w całej sile. Wówczas rząd, posiadając zawsze tę samą siłę absolutną, będzie posiadał minimum siły względnej, czyli zdolności działania ${ }^{33}$.

Monokracja, w której los państwa zależy od skuteczności i politycznej woli jednostki, oraz demokracja absolutna, w której na każdym spoczywa odpowiedzialność publiczna, występują tu jako dwie wykluczające się formy dystrybucji władzy. Pierwsza cechuje się najwyższą, a druga najniższą względną mocą władzy wykonawczej. W obu przypadkach wola partykularna zyskuje przewagę nad wolą powszechną, ale ze skrajnie odmiennych przyczyn: albo z powodu pełnej koncentracji władzy, albo w wyniku jej maksymalnego rozproszenia. Gdyby jednak uznać możliwość zaistnienia tych skrajnych cech w ramach dynamiki jednej sytuacji, to destrukcyjną zależność woli powszechnej od negacji woli partykularnej opisywaną przez Arendt można uchwycić bardziej precyzyjnie. Byłby to scenariusz przechodzenia drugiej formy w pierwszą: wyłaniania się monokracji w warunkach absolutnej demokracji, która z założenia pozostawia wolę partykularną „w całej sile”, obciążając wszystkich jako jednostki odpowiedzialnością publiczną za całość państwa. W rewolucyjnej Francji

„Tak nikczemnie wyrażał swoje zdanie senat w dobie cesarstwa. Niekiedy robiono to ze śmiesznymi ostrożnościami. Tacyt notuje, że za panowania Ottona senatorowie, obrzucając przekleństwami Witeliusza, wywoływali przy tym sztucznie straszliwy hałas, aby tamten, gdyby przypadkiem został władcą, nie mógł wiedzieć, co który z nich powiedział”. J.J. Rousseau, Umowa..., s. 108.

Ibidem, s. 68. 
jako przykład połączenia takiej mocy i niemocy w jednym, wyłaniania się autokracji w warunkach radykalnego dyskursu demokratycznego, posłużyła polityka Komitetu Ocalenia Publicznego. Stronnictwo Robespierre'a, które uznaje siebie za depozytariuszy woli powszechnej w imię przetrwania rewolucji, musi za wszelką cenę dążyć do nadania sobie przynajmniej pozorów powszechnej demokratycznej legitymizacji. Dopiero takie właśnie dążenie do uprawomocnienia za wszelką cenę w warunkach kryzysu zewnętrznego - jest prostą drogą do symbolicznej i realnej negacji „woli partykularnej” w imię interesu publicznego. Dopiero wówczas "interes prywatny” zyskuje status politycznego zła, zostaje uznany za sferę spisków i machinacji, które należy zwalczać na drodze politycznego terroru i spektaklu. Treść polityki przekłada się tym samym na destrukcyjną formę, co próbuje pokazać Hegel w rozdziale Fenomenologii ducha zatytułowanym Wolność absolutna i terror. Ujmuje tę logikę kryzysu w kategoriach sprzeczności między „absolutną wolnością” (wola powszechna) a „rzeczywistą samowiedzą jednostkową" uczestników wydarzeń:

Samowiedza jednostkowa, podobnie jak nie odnajduje siebie w ogólnym dziele absolutnej wolności jako substancji istniejącej, tak też nie odnajduje siebie w czynach właściwych i w indywidualnych działaniach swej woli. Aby ogólność mogła wykonać jakieś dzieło, musi skupić się w jednej indywidualności i wysunąć na czoło jednostkową samowiedzę; ogólna wola jest bowiem wolą rzeczywistą tylko w jakimś „ja”, które jest czymś jednym. Wskutek tego jednak wszystkie inne jednostki zostają wyłączone z czynu jako całości i mają w nim tylko ograniczony udział, tak iż czyn nie może już być dziełem rzeczywistej samowiedzy ogólnej. Ogólna wolność nie może więc stworzyć żadnego pozytywnego dzieła, ani [być źródłem pozytywnego] czynu. Pozostaje jej tylko działanie negatywne; wolność ogólna jest tylko furia zanikania ${ }^{34}$.

Sprzeczność polityki rewolucyjnej opartej na założeniu demokratycznego uczestnictwa polega na tym, że z jednej strony wola powszechna, jako wola wszystkich, musi być wolą niczyją, a z drugiej strony - jako wola - musi być ucieleśniona. „Toteż rząd w ostateczności nie może być niczym innym jak tylko stronnictwem", które jedynie rości sobie prawo do realiza-

34 G.W.F. Hegel, Wolność absolutna i terror, w: idem, Fenomenologia ducha, t. 2, przeł. A. Landman, Państwowe Wydawnictwo Naukowe, Warszawa 1965, s. 186-187. 
cji interesu wszystkich ${ }^{35}$. Owi „wszyscy” zaś, demaskując autokratyczny rząd jako partykularne stronnictwo, stają się dla niego zagrożeniem, a oficjalnie - potencjalnymi wrogami publicznymi.

Rzeczywistością najwyższą i przeciwstawną ogólnej wolności, albo raczej: jedynym przedmiotem, który dla wolności tej może jeszcze zaistnieć, jest wolność i jednostkowość rzeczywistej samowiedzy samej. [...] Stosunek ich do siebie jest stosunkiem zupełnie niezapośredniczonej czystej negacji, jest mianowicie negacją jednostkowości jako istniejącej w tym, co ogólne. Jedynym dziełem i jedynym czynem ogólnej wolności jest przeto śmierć, i to mianowicie taka śmierć, która nie posiada żadnego wewnętrznego zakresu i żadnej wewnętrznej treści ${ }^{36}$.

Wspólnota polityczna, która miała być ciałem moralnym i wspólnym „ja”, w sytuacji kryzysu ujawnia swoje janusowe oblicze. Przeradza się we własne przeciwieństwo, okazując się polityczną przestrzenią wrogich poczynań wszystkich przeciw wszystkim. „Toteż stać się podejrzanym ma to znaczenie i ten sam skutek, co być winnym" ${ }^{37}$, dodaje Hegel, nawiązując do „dekretu o podejrzanych”. Legalna władza rządu na mocy logiki samopotwierdzenia i substytucji przybiera wówczas postać czystej przemocy. Figurą takiej „polityki śmierci” jest Maksymilian Robespierre występujący przeciw „spiskom i hipokryzji”, a punktem kulminacyjnym terroru - nieudany pokazowy proces Dantona jako ucieleśnienia rewolucyjnej wolności i zarazem wszystkich przywar burgeois w jednej osobie ${ }^{38}$.

Zarzut Arendt byłby zatem trafny tylko częściowo. Błąd Rousseau nie polegał na tym, że zdefiniował on konflikt wspólnoty z jednostką jako konflikt moralny. Interes partykularny nie jest sam przez się czymś złym, co więcej, jak podkreśla Jakub Kloc-Konkołowicz: „paradoks polega na tym, że konflikt woli powszechnej z wolą prywatną jest warunkiem sine qua

Ibidem, s. 189. „Tylko zwycięska fakcja nazywa się rządem i w tym właśnie, że rząd jest fakcją, zawarta jest bezpośrednio konieczność jego upadku. I na odwrót: to, że fakcja jest rządem, czyni z rządu fakcję odpowiedzialną za swoje winy”. Ibidem.

Ibidem, s. 187-188.

37 Ibidem, s. 189.

38 „Wolność ogólna” (wola powszechna) dzieli się według Hegla na „na dwa abstrakcyjne człony skrajne, na prostą, sztywną i chłodną ogólność", czego figurą jest postać Robespierre'a, i na „wyosobnioną, absolutną, nieugiętą nieprzystępność i upartą punktowość rzeczywistej samowiedzy", której uosobieniem jest Danton jako swój własny adwokat na pokazowym procesie. Ibidem, s. 187. 
non percepcji wymagań tej pierwszej"39. Rousseau podchodził do konfliktu w sposób nie tyle jednostronnie emocjonalny, ile zbyt wąsko racjonalny, ponieważ utożsamił - jak sama zauważa Arendt - wszelką wolę z artykulacją interesu ${ }^{40}$. Albowiem to właśnie utożsamienie sprawia, że pojęcie woli powszechnej zyskuje charakter abstrakcyjny w sensie Hegla. Wspólna tożsamość konstytuuje się zawsze poprzez wykluczenie różnic i to właśnie sprawiło, że możliwości mediacji między ogółem a jednostką poszukiwał bezskutecznie. Problem nie polega na tym, że wola powszechna z konieczności musi odnosić się negatywnie do wszelkiej partykularności, lecz na braku zapośredniczenia między tymi wymiarami, a w konsekwencji jedna partykularność może występuje przeciw wszystkim innym, jeśli wierzy, że jest ucieleśnieniem woli ogółu. W konsekwencji polityka woli powszechnej jest prowadzona w imię czegoś z góry nierealizowalnego i jako konstruktywna Realpolitik jest czymś niemożliwym. Wynika to stąd, że wola powszechna ma za podstawę formalny stosunek umowy, a w konsekwencji interes wspólny jest tylko formalną neutralizacją pierwotnego konfliktu. Toteż $\mathrm{w}$ toku swego urzeczywistnienia jedynie przywraca ów konflikt $\mathrm{w}$ formie politycznej przemocy, niezależnie od złej lub dobrej woli uczestników wydarzeń czy oceny moralnej samego Robespierre'a ${ }^{41}$.

Czy różnicę między modelem Kanta a modelem Rousseau możemy zatem sprowadzić do przeciwieństwa między dwiema tradycjami polityki - republikańsko-liberalną i demokratyczno-autokratyczną? Kant stałby po właściwej stronie barykady, bo instancją ostateczną - podmiotem - jest bezosobowa zasada państwa prawa, a Rousseau po niewłaściwej, skoro polityka prowadzona w imię volonté générale w rzeczywistości musi się skończyć recydywą autokracji? Sam Rousseau daje podstawy do takiego podejrzenia już w pierwszej księdze Umowy spotecznej. Mówi tam o dwóch wymiarach zobowiązania wynikających z zasady uczestnictwa.

39 J. Kloc-Konkołowicz, Portret..., s. 46. Między innymi to spostrzeżenie skłania autora, aby za Bronisławem Baczką uznać, że Umowa społeczna jest raczej próbą mediacji między modelem Gemeinschaft i Gesellschaft. Ibidem, s. 49.

40 H. Arendt, Kondycja..., s. 78.

41 Nie przypadkiem u Hegla problem zapośredniczenia ogólności i partykularności urasta do rangi najważniejszego zagadnienia co najmniej w dwóch kluczowych obszarach jego myśli: w Logice oraz Filozofii prawa, w ontologii absolutu oraz w teorii etyczności. 
Lud jako ogół należy rozpatrywać jako „zwierzchnika”, czyli jako podmiot uczestnictwa (souverain), a z drugiej strony wszystkich poszczególnych uczestników trzeba postrzegać także jako „poddanych”:

Należy przy tym zaznaczyć, że obrady publiczne, które obowiązują wszystkich poddanych względem [...] zwierzchnika, nie mogą odwrotnie, z powodu odmiennego charakteru każdego z tych stosunków, obowiązywać zwierzchnika względem siebie samego; i że wobec tego sprzeciwia się to naturze ciała politycznego, ażeby zwierzchnik narzucił sobie prawo, którego by nie mógł złamać. Ponieważ może on rozpatrywać siebie tylko ze względu na jeden i ten sam stosunek, jest w sytuacji osoby zawierającej umowę z sobą. Stąd wynika, że nie istnieje i nie może istnieć żadne prawo kardynalne, przymusowe dla ludu jako ogółu, dotyczy to nawet umowy społecznej ${ }^{42}$.

Rousseau wypowiada tu między wierszami tak zwany paradoks suwerenności Carla Schmitta ${ }^{43}$. Władza ludu - o ile można ją nazwać suwerenną - nie może być tylko symbolicznym źródłem porządku prawnego, gwarantem prawomocności ogólnych ustaw tworzonych i egzekwowanych $w$ ramach machiny politycznej. Zasługuje na to miano o tyle, o ile może także ów porządek zawiesić i dopiero ta możliwość stanowi o jej suwerenności. Napięcie właściwe koncepcji Rousseau zyskuje zatem łatwe wyjaśnienie: prawo i instytucje prawa w ostateczności są tylko narzędziem służącym dobru ogółu. A zatem czyste państwo praworządne jest fikcją, ponieważ o podstawach jego prawomocności decyduje zdolność definiowania politycznego dobra i zła, a zatem - wroga. Wyczuwała to Arendt, pisząc, że Rousseau „wyprzedził w ten sposób fatalną niestabilność i niesłowność rządów rewolucyjnych", a nawet zapowiedział fanatyzm cnoty samego Robesspierre'a, dla którego „wola powszechna musi być albo republikańska, albo rojalistyczna" i nie ma między nimi żadnej trzeciej drogi ${ }^{44}$.

42 J.J. Rousseau, Umowa..., s. 24. „Co nie oznacza, żeby to ciało polityczne nie mogło zobowiązywać się względem innych w sprawach nienaruszających tej umowy, gdyż wobec obcych staje się on bytem prostym, jednostką" (niemal bliźniacze sformułowanie pojawia się już w Hobbesowskim Lewiatanie).

43 Por. C. Schmitt, Teologia polityczna i inne pisma, przeł. M.A. Cichocki, Wydawnictwo Znak, Fundacja im. Stefana Batorego, Kraków - Warszawa 2000, s. 33-83.

44 „Owej jedności ludu natchnionej przez jedną wolę nie można mylić ze stabilnością. Rousseau traktował własną metaforę poważnie i na tyle dosłownie, że pojmował naród na podobieństwo ciała kierowanego przez jedną wolę, która - jak w przypadku jednostki ludzkiej - może w każdej chwili zmienić kierunek, nie tracąc tożsamości. Dokładnie w tym sensie Robespierre 
Rousseau posunął tym samym do ostatecznej skrajności ideę autonomii ludu jako suwerena i wyciągnął z niej wnioski na przyszłość: niczym niegraniczona zasada demokracji jest sprzeczna z republikańską ideą rządów prawa i dlatego taka demokracja nie może być liberalna.

Tym bardziej narzuca się pytanie, co się dzieje ze schematem koncepcji Rousseau w momencie, gdy zostaje wkomponowany w nową całość, wpisany w założenia modelu Kanta. Czy formalizm czystego rozumu, w którym nie ma miejsca na złudny platonizm dobra ogółu, unika destrukcyjnej logiki woli powszechnej? Czy Kantowi udaje się uniezależnić od rozwiązań Rousseau i zaprojektować racjonalny model obywatelskiej wspólnoty, który w możliwie najwyższym stopniu jest wolny od przemocy?

\section{4}

Jak już wiemy, Rousseau podsunął Kantowi przede wszystkim nową interpretację wolności, która $\mathrm{z}$ zasady miałaby polegać na zdolności do samoograniczenia. Interpretacji tej towarzyszy refleksja nad związkiem między wolnością a przymusem jako jej przeciwieństwem i dopełnieniem oraz nad naturą prawa jako autonomicznie stanowionej reguły będącej tego związku owocem. „Łamanie woli” w imię „woli powszechnie obowiązującej" z Pomystów... to niemal dosłowne powtórzenie uwagi Rousseau z pierwszej księgi Umowy społecznej o „domyślnym zobowiązaniu”, iż w razie nieposłuszeństwa woli powszechnej każdy zostanie „zmuszony do wolności przez całe ciało (polityczne)" ${ }^{45}$. Krótko mówiąc, przymus jest warunkiem wolności i dlatego musi istnieć prawo.

Prawo jednak w swej formie musi również podlegać ograniczeniom, czego najlepszym dowodem jest imperatyw kategoryczny. „Postępuj tylko według takiej maksymy, dzięki której możesz zarazem chcieć, żeby stała się powszechnym prawem". Formułę tę można wręcz potraktować jako

wołał, że: Il faut une volonté UNE [...] Il faut quelle soit républicaine ou royaliste, a Rousseau podkreślał, że «niedorzecznością jest, żeby wola nakładała na siebie więzy na przyszłość». Wyprzedził w ten sposób fatalną niestabilność i niesłowność rządów rewolucyjnych, a zarazem utwierdził dawne, równie fatalne przekonanie charakterystyczne dla państwa narodowego, że umowy obowiązują tylko tak długo, jak długo służą tak zwanemu interesowi narodowemu". H. Arendt, O rewolucji..., s. 76. 
interpretację zasady ograniczenia ustawodawczej władzy suwerena przez wymóg ogólności ustaw z Umowy społecznej. Podobnie jak „nie może być woli powszechnej w stosunku do przedmiotu partykularnego" - czyli przedmiotem jej władzy może być tylko "cały lud” - tak również działanie moralne musi podlegać zasadzie możliwości uniwersalizacji i nie może dopuszczać wyjątku wobec reguły ${ }^{46}$. Sytuacja komplikuje się jednak, gdy przechodzimy na grunt legalności i prawa zewnętrznego z Metafizycznych elementów teorii prawa.

Tutaj bowiem konieczny związek wolności z przymusem zostaje określony szerzej przez odniesienie do ich negacji, do przemocy i bezprawia. Jak powiada Kant: „wszelkie bezprawie przynoszące uszczerbek wolności zbieżnej z prawem powszechnym, napotkać musi swoje nieuchronne ograniczenie, albowiem przymus kładzie tutaj kres przemocy, z winy której ucierpiała najpierw czyjaś wolność" ${ }^{47}$. Bezprawie, przemoc i wolność to kategorie pierwotne względem stanu prawnego. Prawo poparte przymusem jawi się jako przeciwsiła w służbie wolności. Przymus prawa niejako zajmuje miejsce czystej przemocy, neutralizuje ją i wypiera ${ }^{48}$. Nie tylko w porządku historycznym, ale także w porządku pojęciowym nomos może zatem zaistnieć dopiero poprzez negację anomos, tak jak w doktrynie suwerenności Rousseau, zgodnie z którą prawomocność prawa zakładała u źródeł możliwość zawieszenia go. Jednak proces wyjścia ze stanu natury cechuje się u Kanta inną dynamiką, ponieważ jest wzorowany na liberalnej narracji wyjścia ze stanu naturalnego uspołecznienia w wydaniu Locke’a. Tam jednak porządek władzy obywatelskiej i prawa pozytywnego był postrzegany zgoła inaczej niż u Rousseau, bo w kategoriach instrumentalnie pojmowanej legalności. Jak wyjaśnia Jürgen Habermas:

[...] w liberalnej konstrukcji prawa naturalnego prawa podstawowe odpowiadają zasadom stosunków wykształconych przed powstaniem państwa, które w swej substancji wywodzą się ze stanu natury albo z powstałego w sposób naturalny społeczeństwa i zostają w całości zachowane w ramach porządku politycznego; ba - jedynym celem porządku politycznego jest ich zachowanie. W tych okolicznościach należy w sposób odwoływalny zlecić rządowi zadanie sankcjonowania naturalnych 
praw. Członkowie społeczeństwa zastrzegają sobie powoływanie rządu i kontrolowanie, czy rząd wywiązuje się rzetelnie ze swoich zadań. Jedynie w tym momencie dochodzi do sformułowania woli politycznej - amerykańska deklaracja niepodległości definiuje ów akt jako zgodę rządzonych (consent of governed). Zbyteczne jest natomiast odwołanie się do ciągłego kształtowania woli politycznej. Owo „czynne współdziałanie wszystkich" (l'action de tous) założone w suwerenności ludu przez Rousseau, staje się niezbędne dopiero wtedy, gdy instytucjonalizacja praw podstawowych ma służyć nie tylko zachowaniu substancji istniejącej przed powstaniem państwa, ale dopiero stworzyć, narzucić i utrzymać całościowy ustrój - jeśli nawet ustrój ten jest zorganizowany według zasad natury wbrew zdeprawowanym stosunkom społecznym. Tu konieczna jest wszechmocna władza polityczna, a zatem także demokratyczna integracja tej władzy w stale obecnej woli politycznej ${ }^{49}$.

Różnica między modelem liberalnym a koncepcją Rousseau określa zadanie, z którym Kant musi się zmierzyć w swej filozofii prawa. Problem polega na tym, że w wymiarze formy (ontologii) prawa nie jest on już myślicielem prawa naturalnego, lecz prawa rozumowego, co wynika z inspiracji myślą Rousseau. Zarazem jednak treść (materia) prawa ma wciąż odpowiadać na wyzwania wywodzące się z tradycji liberalnej. Dlatego Kant musi dokonać na jej gruncie implementacji idei „ciągłego kształtowania woli politycznej” (Habermas) - przypomnijmy, że dla Rousseau to kształtowanie woli było koniecznością egzystencjalną. Innymi słowy, Kant musi zinterpretować i opisać consent of governed w kategoriach politycznej woli, ale odnoszącej się do obiektywnego procesu cywilizacyjnego, zwłaszcza w newralgicznym dla tej tradycji obszarze prawa własności. To trudne zadanie określa strategię uzasadniania prawnej formalizacji relacji społecznych z Metafizyki moralności.

W pierwszej części tego dzieła, zatytułowanej Metafizyczne elementy teorii prawa, stosunek między stanem naturalnym a stanem prawnym przyjmuje postać rozróżnienia pojęciowego na „prawo prywatne” i „prawo publiczne”. Narrację Kanta można w skrócie przedstawić następująco: ongiś, w stanie natury, istniało przedpolityczne i tylko prowizoryczne „prawo prywatne”, które w ustroju obywatelskim jest zastępowane „prawem publicznym” o charakterze „peremptorycznym” (obowiązującym ostatecznie, niezawodnie). Oto na naszych oczach, w epoce Oświecenia 
- powiedziałby Kant jako trybun ludowy - dawne prawo „prywatne” zostaje podniesione do godności prawa rozumu. Na tym jednak retorycznie nie poprzestaje. Ten sam rozum - zstępując z wyżyn swego autorytetu - nie jest już tylko celem, wzorcem, do którego zmierzamy, lecz sam domaga się, aby zastąpić prawo naturalne prawem publicznym. Co więcej, rozum nie czyni tego w zwykłym trybie wyznaczania postulatów praktycznych, tak aby powinność zaistnienia danego stanu rzeczy stanowiła przynajmniej o konieczności jego niesprzecznego pomyślenia. Na odwrót: „dążenie do [stanu obywatelskiego] jest koniecznością, a nawet zgoła obowiązkiem" ${ }^{50}$. Konieczność, a nawet zgoła obowiązek - następstwo osobliwe dla Kanta. I, last but not least, "tkwienie w stanie naturalnym i pragnienie tkwienia w nim” stanowi "najpotworniejsze bezprawie”, ostrzega. Albowiem - tym razem argument ma w sobie coś tautologicznego - „nie jest to stan prawny, lecz nieopisana dzicz, w której nikt nie może być pe-

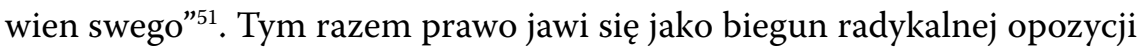
o charakterze kryptomoralnym. Niemal cała ludzkość, z małymi wyjątkami w Ameryce Północnej i Europie, każdego dnia oddaje się najpotworniejszemu bezprawiu. Krótko mówiąc - argumentacja ta stanowi klasyczny przypadek Freudowskiej „argumentacji w sprawie kociołka”, składającej się ze sprzecznych argumentów w tej samej sprawie, których zestawienie wyraża coś innego niż każdy z nich z osobna ${ }^{52}$. Te trzy możliwości wyraźnie się bowiem wykluczają: albo chodzi o powinność dostrzeżenia konieczności cywilizacyjnej i poddania się jej, albo o wynikającą z niej moralną powinność działania w jej sprawie (choć nie bardzo wiadomo, co miałoby to oznaczać, jeśli jako kantyści nie chcemy popaść w błąd naturalistyczny), albo o moralny nakaz walki z dziczą i bezprawiem, który, jako wezwanie do

50 Por. ibidem, s. 77, 87. „Ustrój obywatelski - pomimo iż jego rzeczywista postać jest rzeczą dowolną i przypadkową - zachowuje mimo wszystko wartość obiektywną; znaczy to, że dążenie do niego jest koniecznością, a nawet zgoła obowiązkiem”. Wątek „przypadkowości i dowolności” potwierdza naszą tezę interpretacyjną, że „konieczność”, o której mowa, ma charakter cywilizacyjny, ponieważ nie wiąże się z jakimś bliżej historycznie określonym ustrojem republikańskim.

51 Ibidem, s. 150.

52 „1. Zwracam ci nowy kociołek. 2. Dziury były w nim już wtedy, gdy mi go pożyczyłeś. 3. Nigdy zresztą nie pożyczałeś mi kociołka”. S. Freud, Objaśnianie marzeń sennych, przeł. R. Reszke, Wydawnictwo KR, Waszawa 2007, s. 117. 
działania, zakłada przecież, że żadnej obiektywnej konieczności tu nie ma. Również ustanowienie porządku prawnego jest albo konieczną transformacją i eliminacją niedomagań kondycji naturalnej oraz zastąpieniem jej nowym sformalizowanym porządkiem rozumnym, albo utrwaleniem i zabezpieczeniem tego, co w porządku tym już prowizorycznie istnieje. Przy bliższym wejrzeniu sprzeczność ta okazuje się jeszcze bardziej złożona.

Kant przyznaje bowiem także - jak gdyby tego było mało - iż w stanie naturalnym „możemy znaleźć społeczności rządzące się pewnymi regułami (np. małżeństwo, patriarchat, stadło domowe, i jakie tam tylko)”. Podkreśla, że takie „prawo prywatne”, w momencie, gdy wchodzi w zakres prawa publicznego, „nie zawiera żadnych nowych obowiązków w porównaniu z tymi, które pomyśleć się dają dla stanu naturalnego ${ }^{53}$. Różnica treści zachodząca między prawami zwyczajowymi (Kantowskie „prawo prywatne") a stanowionym prawem prywatnym (w zwykłym sensie) jawi się wręcz jako nieistotna. Legalność i prawomocność prawa pozytywnego ma polegać na gwarantowanej sankcji siłowej, publicznym uznaniu, a w razie potrzeby na możliwości odwołania się adresatów prawa do kryteriów uniwersalistycznych. Mimo to Kant chce jednak zakomunikować coś więcej i w tym punkcie wychodzi chyba na jaw ukryty sens jego argumentacji:

Stan naturalny jest siedliskiem niesprawiedliwości (iniustus) nie z tej przyczyny, że stosunki między ludźmi oparte tam były na gwałcie i przemocy; był to przecież stan bezprawia (status iustitia vacuus), w którym skoro tylko jakieś prawo stało się źródłem sporu (ius controversum) - nigdzie nie można było znaleźć sędziego zdolnego wydać kompetentny wyrok; z takiego porządku rzeczy wynikało tedy jasno, że konieczne jest przejście do stanu prawnego, i że każdemu wolno uciec się zgoła do przemocy, aby nakłonić do tego innych. Bo chociaż według wszelkich danych prawo dopuszczało tam nabywanie przedmiotów zewnętrznych w drodze zajęcia bądź umowy, wszystko to miało charakter prowizoryczny ${ }^{54}$.

53 I. Kant, Metafizyka..., s. 148.

54 Ibidem, s. 153. W oryginale: „Zwar durfte sein natürlicher Zustand nicht eben darum ein Zustand der Ungerechtigkeit (iniustus) sein, einander nur nach dem bloßen Maße seiner Gewalt zu begegnen; aber es war doch ein Zustand der Rechtlosigkeit (status iustitia vacuus), wo, wenn das Recht streitig (ius controversum) war, sich kein kompetenter Richter fand, rechtskräftig den Ausspruch zu tun, aus welchem nun in einen rechtlichen zu treten ein jeder den anderen mit Gewalt antreiben darf; weil, obgleich nach jedes seinen Rechtsbegriffen etwas Äußeres durch Bemächtigung oder Vertrag erworben werden kann, diese Erwerbung doch nur provisorisch ist, so lange sie noch nicht die Sanktion eines öffentlichen Gesetzes für sich hat, 
Wywód ten wyraźnie sugeruje, że stan naturalny, jako zwykle już związany z jakimś prawem zwyczajowym, nie był przestrzenią czystej przemocy, ale raczej sytuował się wciąż poniżej pewnego progu. Był stanem bezprawia (Rechtslosigkeit) w znaczeniu, by tak rzec, próżni sprawiedliwości (status iustitia vacuus). Historycznym świadectwem tego pośredniego charakteru był brak sformalizowanych reguł wymiaru sprawiedliwości oraz - co za tym idzie - ciągła niepewność odnośnie do praw własności. Ukryty sens Kantowskiej argumentacji wychodzi oczywiście na jaw w przedostatnim zdaniu: „każdemu wolno uciec się zgoła do przemocy, aby nakłonić do tego innych"55. Przejście do stanu prawnego jest koniecznością bezwarunkową, absolutną, musi się dokonać niemal za wszelką cenę. Co znamienne, Kant nie uzasadnia tu owego postulatu odwołaniem do wartości humanitarnych - choćby domyślnie, jako zwalczania „dziczy” lub barbarzyństwa - lecz potrzebą stabilności prawnej (bezpieczeństwa) w sferze nabywania dóbr. Tak właśnie uzasadnia swe przyzwolenie na coś, co należałoby chyba określić mianem przemocy propaństwowej albo (pre) obywatelskiej. Kilka stron wcześniej, gdy pisze w tym samym tonie o wypływającym ze stanu naturalnego "postulacie prawa publicznego, rozkazującym każdemu opuścić tamten stan", dodaje kolejne uzasadnienie:

Zasadność tego aktu można wywnioskować w sposób analityczny z pojęcia prawa, regulującego zewnętrzne stosunki osobowe, w przeciwieństwie do przemocy (violentia $)^{56}$.

weil sie durch keine öffentliche (distributive) Gerechtigkeit bestimmt, und durch keine dies Recht ausübende Gewalt gesichert ist" (I. Kant, Metaphysik der Sitten, par. 44).

Wcześniej mówi też o „prawie przymuszenia każdej osoby, z jaką się zetkniemy, do wstąpienia razem z nami w ustrój, gdzie mienie podlegać będzie ochronie". Ibidem, s. 77. Kant zdawał sobie sprawę, że podobny sposób myślenia może prowadzić do nadużyć ze strony kolonizatorów obu kontynentów amerykańskich - do „oszukańczych machinacji i przekupstwa” wobec „Hotentotów czy mieszkańców Nowej Holandii”, do „bezwstydnego wykorzystania władzy nieliczącego się z pierwotnymi posiadaczami”. Na pytanie: „Czy wolno nam przemocą przywieść owych barbarzyńców do stanu prawnego?” udziela jednak ostatecznie odpowiedzi przyzwalającej, powołując się na maksymę, że „natura nie znosi próżni” - „gdyby nie te praktyki, to niezmierzone połacie ziemi leżące na antypodach naszej planety - dziś gęsto zaludnione wciąż świeciłyby pustkami, przez co ludzkość chybiłaby celu, gwoli którego została powołana do istnienia". I. Kant, Metafizyka..., s. 90 i nast. 
Słowem - prawo będące oficjalnie przeciwieństwem przemocy może się przemocą posłużyć przeciw bezprawiu, nawet jeśli bezprawie wcale do końca bezprawiem nie jest, ponieważ taka przemoc służy powszechnemu dobru - obywatelskiej wolności. Prawo „ma prawo” do przemocy, zanim jeszcze istnieje. Przysługuje mu performatywna zdolność prawomocnego (słusznego i legalnego) samoustanowienia. Tak można podsumować pokrętną logikę Kanta z Metafizyki moralności.

Oznacza to, że wbrew naszemu wyjściowemu przeciwstawieniu dwóch zasad - prawa i uczestnictwa jako najwyższych zasad polityki również u Kanta instancją nadrzędną okazuje się „wspólne dobro”, tylko że występuje ono teraz w masce performatywnej mocy samoustanowienia i ochrony porządku prawa. Tym samym prawo zostaje również ugruntowane w porządku zewnętrznym wobec samego siebie, aczkolwiek logika tego ugruntowania jest już inna. U Rousseau źródłem prawomocności prawa (jego słuszności i zarazem legalności) była wspólna wola podmiotu uczestnictwa, w istotnej dla niego cesze zdolności do podjęcia wszelkiej możliwej decyzji dotyczącej własnego losu. Natomiast tezę Kanta, iż prawny „przymus kładzie [...] kres przemocy, z winy której ucierpiała najpierw czyjaś wolność" ${ }^{\prime 7}$ należy teraz uzupełnić o zarysowany już obraz sytuacji przejściowej. Jest to scenariusz „transformacji” jako momentu lub procesu, w którym prawo dopiero występuje na scenę w warunkach połowicznego bezprawia i zwraca się przeciw niemu. Właśnie w toku tego procesu, który nie jest przecież obojętny dla historii Rechtsstaat, wychodzi na jaw istotna treść samej zasady prawa. Jeżeli bowiem zasadność rozkazu opuszczenia stanu naturalnego wynika „w sposób analityczny z pojęcia prawa" ${ }^{\text {, }}$ to Kant posługuje się tym terminem w jakimś nowym i zawężonym znaczeniu. Pojęcie to implicite („,analitycznie”) zakłada dla niego prawomocność (powinność, słuszność, legalność) ekspansji prawa w przestrzeń pozaprawną. A to chyba znaczy, że Kant pod postacią prawa projektuje raczej pewien model strategiczny lub wzorzec. Jest to wzorzec (sformułowanie to może wydać się nieprecyzyjne, ale trudno o inne) „przyciągania się" wymiaru moralnego i legalnego, powinności i normy prawnej, 
racji praktycznej i czystego przymusu - co znajduje wyraz w dziwacznym sformułowaniu „konieczność, a nawet zgoła obowiązek" ${ }^{59}$. Wzorzec ten można za Michelem Foucaultem określić mianem postulatu i zarazem przymusu normalizacji stosunku społecznego na drodze stanowienia prawa jako podstawowego modus operandi władzy dyscyplinarnej. Ujmując rzecz w kategoriach Waltera Benjamina, byłaby to „przemoc stanowiąca prawo" (gesetzgebende Gewalt), ale taka, która od początku i z założenia ma już na celu jedynie zachowanie porządku prawnego (rechtserhaltende Gewalt), czyli monopolizację siebie samej, monopolizację przemocy ${ }^{60}$. To właśnie wyraża Kantowskie przeciwstawienie „prawnego przymusu” i "przemocy” (violentia) pozaprawnej. Kantowska Metafizyka moralności jest czymś w rodzaju normatywnej doktryny przemocy prawa - przemocy ustanawiającej siebie jako legalną $\mathrm{i}$ „zachowującą prawo", przemocy o tyle państwotwórczej, o ile zarazem „policyjnej”. Bezpieczeństwo bowiem jest jej zasadą nadrzędną, zgodnie z którą, jak powiada Marks, „całe społeczeństwo po to tylko istnieje, by zagwarantować każdemu swemu członkowi zachowanie jego osoby, jego praw i jego własności”61.

59 Por. wyżej. Warto także przypomnieć, że jeśli chodzi o potocznie rozumiany stosunek prawa do moralności, to Kant nie był typowym liberałem - nie traktował systemu prawnego jako neutralnego narzędzia w służbie regulacji życia społecznego, czegoś w rodzaju wspólnego minimum które musi być obojętne względem zawsze bardziej restrykcyjnych i często wzajemnie sprzecznych doktryn moralnych, które dlatego mogą na jego gruncie współistnieć, tak jak na przykład islam, katolicyzm i ateizm na gruncie współczesnego państwa liberalnego. Prawo mogło być dla niego dyscyplinującym przekaźnikiem zasad etyki, a jego związek z moralnością miał się z czasem zacieśniać.

60 Walter Benjamin zwraca z tym kontekście uwagę na „zaskakującą możliwość, że dążenie prawa do zmonopolizowania przemocy i odebrania dostępu do niej jednostkom tłumaczy się chęcią ochrony nie tyle celów prawnych, ile samego prawa. Innymi słowy, że przemoc, którą nie rozporządza aktualne prawo, stanowi dlań zagrożenie - bynajmniej nie za sprawą celów, do których mogłaby być użyta, lecz za sprawą samego swego istnienia poza sferą prawa". To napięcie między przemocą legalną a działaniem spoza prawa obrazuje figurą „wielkiego" zbrodniarza, który - na przekór prawu - wzbudza sympatię tłumu. Wydaje się, że to samo napięcie próbuje na swój sposób wyrazić Kant usiłując skonstruować ścisłe przeciwieństwo między prawem a bezprawiem jako status justitia vacuus (por. wyżej). W. Benjamin, Przyczynek do krytyki przemocy, przeł. A. Lipszyc, „Kronos” 2009, nr 4, s. 28.

61 „Bezpieczeństwo jest to najwyższe socjalne pojęcie społeczeństwa obywatelskiego, jest to pojęcie policji, zgodnie z którym całe społeczeństwo po to tylko istnieje, by zagwarantować każdemu swemu członkowi zachowanie jego osoby, jego praw i jego własności. W tym znaczeniu nazywa Hegel społeczeństwo obywatelskie «państwem z potrzeby i z rozsądku». Przez pojęcie 
Na czym zatem polegałaby różnica między Kantem a Rousseau? Oba modele są możliwe do pomyślenia tylko przy założeniu, że stan przed umową jest postrzegany jako stadium kryzysu. Jednak Kantowskie Rechtsstaat, inaczej niż republika Rousseau, nie jest jedynie środkiem na drodze do zażegnania kryzysu i przywrócenia obywatelom ich integralności, lecz celem ostatecznym w sferze polityki, dla której moralność stanowi jedynie niedościgniony wzorzec. Oznacza to ni mniej ni więcej, że ekspansja zasady prawa - zarówno w wymiarze ekstensywnym (geograficznym), jak i intensywnym (stosunki społeczne) - musi zakładać, że kryzys ten będzie się odtwarzał wciąż na nowo. Potencjalnie będzie to stan kryzysu permanentnego towarzyszcego państwu prawa w jego historii i na jego obrzeżach. Trudno bowiem zakładać, że "społeczeństwo obywatelskie powszechnie rządzące się prawem" w skali światowej zostanie zrealizowane szybko i bezboleśnie, a nawet że dojdzie do tego w jakiejś najbliższej przyszłości. Oznacza to, że ludzie, którzy na przestrzeni historii stawania się Rechtsstaat będą dostrzegać konieczność prawnej regulacji stosunku społecznego i organizacji światowego systemu prawnego, otrzymują od Kanta wyjątkowe prawo, aby zmuszać do tego innych na drodze legalnej przemocy. Właśnie tu pojawia się rola dla Kantowskiego Robespierre'a jako depozytariusza tak rozumianej obywatelskiej woli powszechnej. Ów Robespierre - jako ucieleśnienie cnoty i przemocy w jednym - nie będzie już jednak rewolucjonista oddanym sprawie równości i wolności, lecz państwotwórczo-policyjnej sprawie normalizacji i prawa. Byłby to ktoś w rodzaju depozytariusza obywatelskiego etosu „interwencjonizmu prawnego”, przymusu normalizacji stosunku społecznego, zwłaszcza w służbie prawa własności ${ }^{62}$.

Karol Marks żartował w Kapitale, że „prawo i «praca» były od niepamiętnych czasów jedynymi środkami bogacenia się, oczywiście za każdym razem z wyjątkiem «roku bieżącego»" ${ }^{63}$. Sugestia była jasna - w ramach państwa liberalnego prawo konserwuje i legitymizuje historycznie zaist-

bezpieczeństwa nie wznosi się społeczeństwo obywatelskie ponad swój egoizm. Przeciwnie, bezpieczeństwo jest zabezpieczeniem jego egoizmu". K. Marks, W kwestii żydowskiej, przekład zbiorowy, w: idem, F. Engels, Dzieła, t. 1, Książka i Wiedza, Warszawa 1962, s. 442.

62 Sformułowanie „interwencjonizm prawny” w podobnym kontekście pojawia się u Michela Foucaulta. Zob. M. Foucault, Narodziny biopolityki, przeł. M. Herer, Wydawnictwo Naukowe PWN, Warszawa 2011, s. 178.

63 K. Marks, Kapitał, w: idem, F. Engels, Dzieła, t. 23, Książka i Wiedza, Warszawa 1968, s. 849. 
niałe stosunki przemocy. Kantowska "konieczność, a nawet powinność" ingerencji $\mathrm{w}$ porządek przedprawny w zawsze wyjątkowych warunkach „roku bieżącego” była jedną z pierwszych oznak odkrycia tej nowej logiki.

\section{Bibliografia}

Arendt H., O rewolucji, przeł. M. Godyń, Wydawnictwo X, Kraków 1991.

Foucault M., Narodziny biopolityki, przeł. M. Herer, Wydawnictwo Naukowe PWN, Warszawa 2011.

Freud S., Objaśnianie marzeń sennych, przeł. R. Reszke, Wydawnictwo KR, Warszawa 2007.

Habermas J., Prawo naturalne a rewolucja, przeł. M. Łukasiewicz, w: idem, Teoria i praktyka, Państwowy Instytut Wydawniczy, Warszawa 1983.

Habermas J., Przedpolityczne podstawy demokratycznego państwa praworzadnego?, w: idem, Między naturalizmem a religia, przeł. M. Pańków, Wydawnictwo Naukowe PWN, Warszawa 2012.

Hegel G.W.F., Fenomenologia ducha, t. 2, przeł. A. Landman, Państwowe Wydawnictwo Naukowe, Warszawa 1965.

Kant I., Do wiecznego pokoju. Projekt filozoficzny, przeł. M. Żelazny, Comer, Toruń 1995.

Kant I., Przypuszczalny poczatek ludzkiej historii, przeł. M. Żelazny, Comer, Toruń 1995

Kant I., Metafizyka moralności, przeł. E. Nowak, Wydawnictwo Naukowe PWN, Warszawa 2005.

Kloc-Konkołowicz J., Portret Rousseau, „Przegląd Filozoficzny” 2000, nr 1 (33).

Radbruch G., Filozofia prawa, przeł. E. Nowak, Wydawnictwo Naukowe PWN, Warszawa 2009.

Rousseau J.J., Rozprawa o pochodzeniu i podstawach nierówności między ludźmi, w: idem, Trzy rozprawy z filozofii społecznej, przeł. H. Elzenberg, Państwowe Wydawnictwo Naukowe, Warszawa 1956.

Rousseau J.J., Umowa społeczna, przeł. A. Peretiakowicz, Wydawnictwo Naukowe PWN, Warszawa 2010.

Schmitt C., Teologia polityczna i inne pisma, przeł. M. Cichocki, Wydawnictwo Znak, Fundacja im. Stefana Batorego, Kraków - Warszawa 2000.

Siemek M.J., Filozofia wobec wyzwań społecznej modernizacji, w: idem, Hegel i filozofia, Oficyna Naukowa, Warszawa 1998.

Wonicki R., Spór o demokratyczne państwo prawa, Wydawnictwo Akademickie i Profesjonalne, Warszawa 2007. 


\section{Kant and Rousseau. The Logic of Law and the Logic of Participation, or Two Necessities}

The aim of the article is to compare two concepts of the social contract - formulated by Immanuel Kant and Jean Jacques Rousseau respectively - in the context of their philosophical diagnoses regarding human nature, culture, politics and the historical dynamics of civilization. The author focusses on the essence of the impact $D u$ contrat social has on Kant and the extent to which he manages to overcome the tension between the modern Republican idea - which he develops on this basis - and the tradition of classical liberalism, which he continues to follow. He considers Rousseau's model with regard to the conflict between the democratic principle of people's sovereignty and the Republican rule of law in discussions with Hegel, Arendt, Habermas and in reference to the French Revolution. Next, he conducts a critical analysis of the Kantian project of Rechtsstaat in light of its conceptual dependence on Rousseau - the founding of this project on the liberal tradition turns out to be problematic and burdened with ideological symptoms. Since Kant's thought lies at the root of the modern concept of liberal rule of law, these symptoms show the limitations of Rechtsstaat resulting from its own normative assumptions.

\section{Keywords:}

ImManuel Kant, Jean-Jacques Rousseau, Social Contract, RULE OF LAW, PARTICIPATION, LIBERALISM, REPUBLICANISM. 